DE85 010344

\title{
A Compact L-Edge Densitometer for Uranium Concentration Assay
}

\author{
V. L. Brooks* \\ P. A. Russo \\ J. K. Sprinkle, Jr.
}

-New Mexico Institute of Mining and Technology, Socorro, NM 87801.

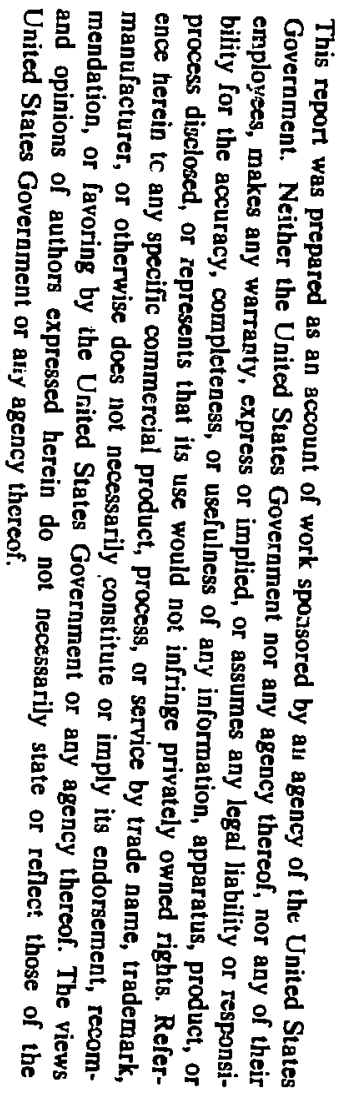




\section{CONTENTS}

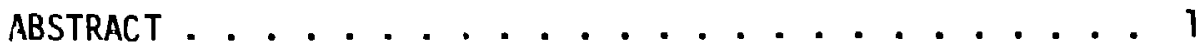

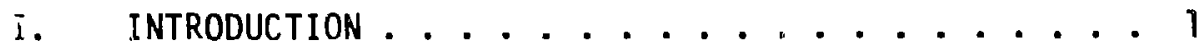

A. L-Edge Performance in Field Tests . . . . . 1

B. L-Eage Assay Principles ......... 3

C. Practical Limitacions to L-Erlge Applications . - 6

D. Scc pe of Compact L-Edge Evaluation . . . . . 8

II. EXPERIMENTAL METHODS ............. 8

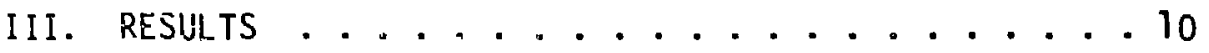

IV. DISCUSSTON .................. 17

A. Performance of the Compact L-Edge Inst;"ument . . 17

B. Comparison of Analysis Methods ........ 18

$\therefore$ Concentration Range for Precise and Timely Assay . . . . . . . . . 19

D. Fission Product Sensitivity Limits . . . . . 24

E. Summary and Conclusions .......... 24

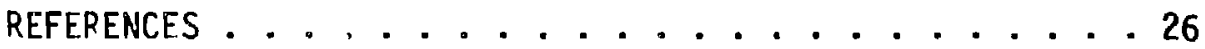


A COMPACT L-EDCI: DENSITOMETER FOR URANILIM CONCENTR.ATION ASSAY

by

M. L. Brooks, P. A. Russo, and J. K. Sprinkle, Jr.

\begin{abstract}
A new L-edge densitometer has been designed around a compact, commercial $x$-ray generator weighing less than $5 \mathrm{~kg}$. The dc generator $x$-ray spectrum was tailorad to produce a continuum of $x$-ray energies from 14 to $20 \mathrm{keV}$. The $x$ rays were transmittec through uranium reference solutions, and the measured transmissions near the uranium $L_{I I I}$-absorption edge were used to compute the uranium concentration assay result. The range of uranium concentrations in the reference solutions inciuded 5 to $50 \mathrm{~g} / \ell$. In this concentration range, the assay uncertainty for short count times and the flatness of the specific assay response were better than $0.5 \%$. Thus, the precision and accuracy of this compact densitometer are equal to those demonstrated previously for the L-edge technique. The compact dimensions and optimized transmission geolnetry increase the practicality, versatility, and range of the L-edge applications.
\end{abstract}

\title{
I. INTRODUCTION
}

A. L-Edge Performance in Ficild Tests

$\mathrm{L}_{\text {III }}$-absorption-edge densitometry ${ }^{1,2}$ is a nondestructive assay technique that gives individual concentrations of single or multiple elemental components in solution. The method has been demonstrated for assay of uranium and plutonium ccncentrations in a variety of field test ${ }^{j-6}$ situations. Good precision and accuracy in short count times (better than $0.5 \%$ in 20 min or less) are achieved for concentrations of special nuclear materials (SNM) in the range of 3 to $300 \mathrm{~g} / l$. This performance, along with the insensitivity of the L-edge assay response to sample radioactivity and to most matrix components, 
has given the technique a potential role as a safeguards assay tonl in reprocessing or scrap recovery facilities.

Field testing of an L-edge instrument for demonstration of assay precision took place during a 2-yr (1978-1980) evaluation at the Savannah River Laboratory (SRL). ${ }^{3}$ The L-edge solution cell was plumbed directly into a bypass line on the coprocessing demonstration facility glove box at SRL. Concentrations of uranium and plutonium in solutions of single or mixed SNM components in the range of 1 to $100 \mathrm{~g} / \mathrm{l}$ were assayed by the instrument. A second, extensive field evaluation of the precision and accuracy of the L-edge instrument took place at the USDOE New Brunswick Laboratory (NBL) in 1980-1981. " The solution categories and concentrations includied the range addressed by the SRL testing. The evaluation was controlled to assure that the solution reference concentrations used for comparison with the L-edge results were both accurate and precise (exceeding the accuracy and precision of the L-edge assay by an order of magnitude), as well as representative of the actual solutions analyzed by the L-edge instrument. The NBL evaluation included a demonstration of the insensitivity of the L-edge assay to solution matrix variations. A third field test demonstrated application of the L-edge method to on-line nuclear materials accounting in near-real time. This took place in 1981 at the Allied General Nuclear Services (AGNS) reprocessing facility in Barnwell, South Carolina. 5 The L-edge solution cell was plumbed in series with a bypass on the aqueous product stream from tr. second extraction in the plutonium cycle. The bypass was routinely used for withdrawal and external analysiz of solutions. The L-EIge assays of the flowing solutions, precise to $0.7 \%$, were available every 5 min for autcmatic shipping to the materials control and ac counting system (MACS) computer, which correlated these and other near-real-time assay results to draw wimely materials balances. The l-edge instruinent nperated continuously for the 7-day cold-run demonstration, measuring uranium concentrations from $0 \mathrm{~g} / \mathrm{l}$ (startup) to $60 \mathrm{~g} / \mathrm{l}$. Comparisons between the L-edge results and external samp'e assays, as woll as comparisons with other on-line assay results, were consistent within the known uncertainties.

In-house testing of the L-edge method has taken place at los Alamos since 1977. The sensitivity of the assay to the presence of fission products in the assay solutions was examined using the instrument that was ficld tested at SRL and NBL.6 The results showed that the L-edge method can be applied to 
reprocessing plant solutions beyond the first separation cycle with no observable bias in the assay results.

\section{B. L-Edge Assay Principles}

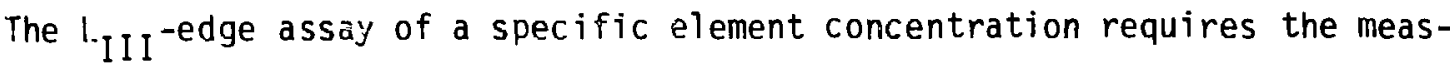
urement of the transmissions of gamma rays at two fixed energies through the solution. The two energies must bracket as closely as possible the $L_{\text {III }}$-absorption edge of the elemertal species heing analyzed. This energy (the $\mathrm{L}_{\text {III }^{-}}$ electron binding energy) is $17.17 \mathrm{keV}$ for uranium and $18.06 \mathrm{keV}$ for plutonium. The resolution of HPGe or Si(Li) detectors permits the simultaneous assay of uranium and plutonium by the L-edge method. The transmitted gamma rays originate from an exterrial source. To reduce background that originates from the sample, the sample-to-detector jeometry is collimated and then the source strength established so that the detector count rate is dominated by gamma rays that originate from the external source.

The transmission of gamma rajs through a sample is the ratio of intensities, $I / I_{0}$, of the incident and transmitted radiation. For a fixed gamma-ray energy $i$ and a two-component solution consisting of matrix $m$ ard uranium $u$, the transmission can be given as a product of two exponentials:

$$
T_{i}=e^{-\mu} i u^{\rho} u^{x} e^{-\mu} i m^{\rho} m^{x},
$$

where ${ }_{i u}$ and $\mu_{i m}$ are the gamma-ray mass attenuation coefficients at energy $i$ for the uranium and matrix, respectively, $\rho_{u}$ and $\rho_{m}$ are the concentrations (densities) of uranium and matrix, respectively, and $x$ is the sciution thickness. If the $\rho$ values are in units of $\mathrm{g} / \mathrm{cm}^{3}$ and $x$ is in units of $a m$, then the units of $\mu$ are $\mathrm{cm}^{2} / \mathrm{g}$.

-igure 1 is a plot of gamma-ray mass attenuation coefficients vs gamma-ray energy for varicus materials. The sharp discortinuities in the energy dependence of the $\mu$ values at the electron binding energies are illustrated for uranium and plutonium. Of all the absorption edges, the (lowest energy) LIII 


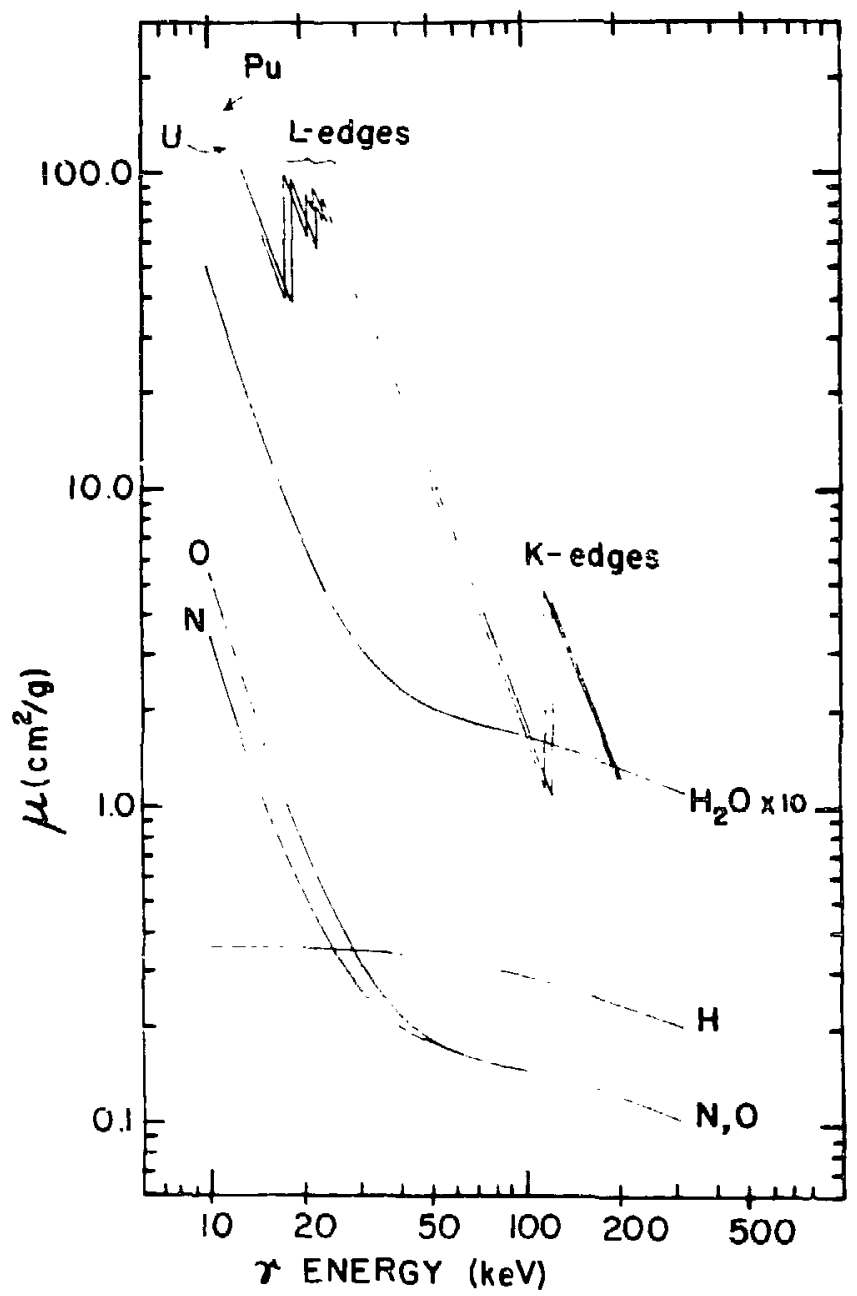

Fig. 1. A log-log plot of the mass attenuation coefficient $(\mu)$ vs gamma-ray energy for uranium, plutonium, and the matrix materials--water, hydrogen, nitrogen, and oxygen.

edge has the largest change, $\Delta \mu$, in the mass absorption coefficient for a given element.

The absorption-edge assay method can be illustrated by defining two energies $L$ and $H$ (low and high, resuectively) that bracket a specific absorption edge of one and only one element, uranium. Using the form of Eq. (i), a iransmission ratio can be defined as

$R=\frac{T_{L}}{T_{H}}=e^{-\Delta \mu} u^{\rho} u^{x} e^{-\Delta \mu m^{\rho} m^{x}}$, 
where

$$
\Delta \mu_{u}=\mu_{L u}-\mu_{H u}
$$

and

$$
\Delta H_{m}=H_{L m}-\mu_{H m}
$$

Taking the logarithm of both sides of Eq. (2) gives

$$
-\ell n R=\Lambda \mu_{u} \rho u^{x}+\Delta \mu_{m} \rho m^{x}
$$

Because $A_{u} \gg c u_{m}$, the matrix term in Eq. (3) can be ignored to give

$$
\rho=\frac{-\ln R}{\Lambda \mu x}
$$

where

$$
\begin{aligned}
o & =\rho_{u} \text { and } \\
\Delta \mu & =\Delta \mu_{u} \text {. }
\end{aligned}
$$

The quantity $R$ can be easily determined using high-resolution gamma-ray spectroscopy to measure transmission at the two energies $L$ and $H$. For a sample 
cell of fixed path length $x$, the quantity $\Delta \mu x$ is consicnt. This constant can be determined empiricaily by absorption-edge measurements of reference solutions with well-defined uranium concentrations.

The relative uncertainty in the value of $\rho$ determined by Eq. (4) is

$$
\frac{\delta_{\rho}}{\rho}=\frac{\delta R}{R \Lambda \mu \rho x}
$$

Because of the appearance of $\Lambda \mu$ in the denominator of this expression for relative uncertainty, the LIII-absorption-edge assay is sensitive over a larger concentration range than the K-absorption-edge assay.

\section{Practical Limitations to L-Edge Applications}

The equipment required for the $L$-edge instruments that have been tested previously is illustrated in Fig. 2, which is a photograph of the AGNS L-edge densitometer. The rack at the left in Fig. 2 holds the required equipment for the measurament station. The remaining equipment (signal processing, data processing, and data storage units in the tall cabinet at the left and the hard-copy unit at the right) can be located remotely from the area where the solutions reside.

The major limitations of the L-edge method are the size of the measurement station equiprent and the requirement for thin or low-Z windows on the sample cell for reasonable transmission of $x$ rays in the 17- to 18-keV region. Space is extremely limited in typical plant environments, and hardening of equipment against the effects of corrosive atmospheres in solutions-handling areas is more difficult with bulky equipment. Most important is the difficulty of satisfying the containment requirements for plutonium solutions with bulky measurement station equipment and thin or $10 w-Z$ sample cell windows.

The measurement station equipment shown in Fig. 2 for the AGNS L-edge densitometer is identical to that designe' for the SRL/NBL instrument. It includes a 50-keV x-ray generator, which is responsible for the bulk of this equipment, a sample cell, and a Si(Li) gamma-ray detector. The flow-through sample cell is fabricated of stainless steel and fitted with two 0.8-mm-thick 


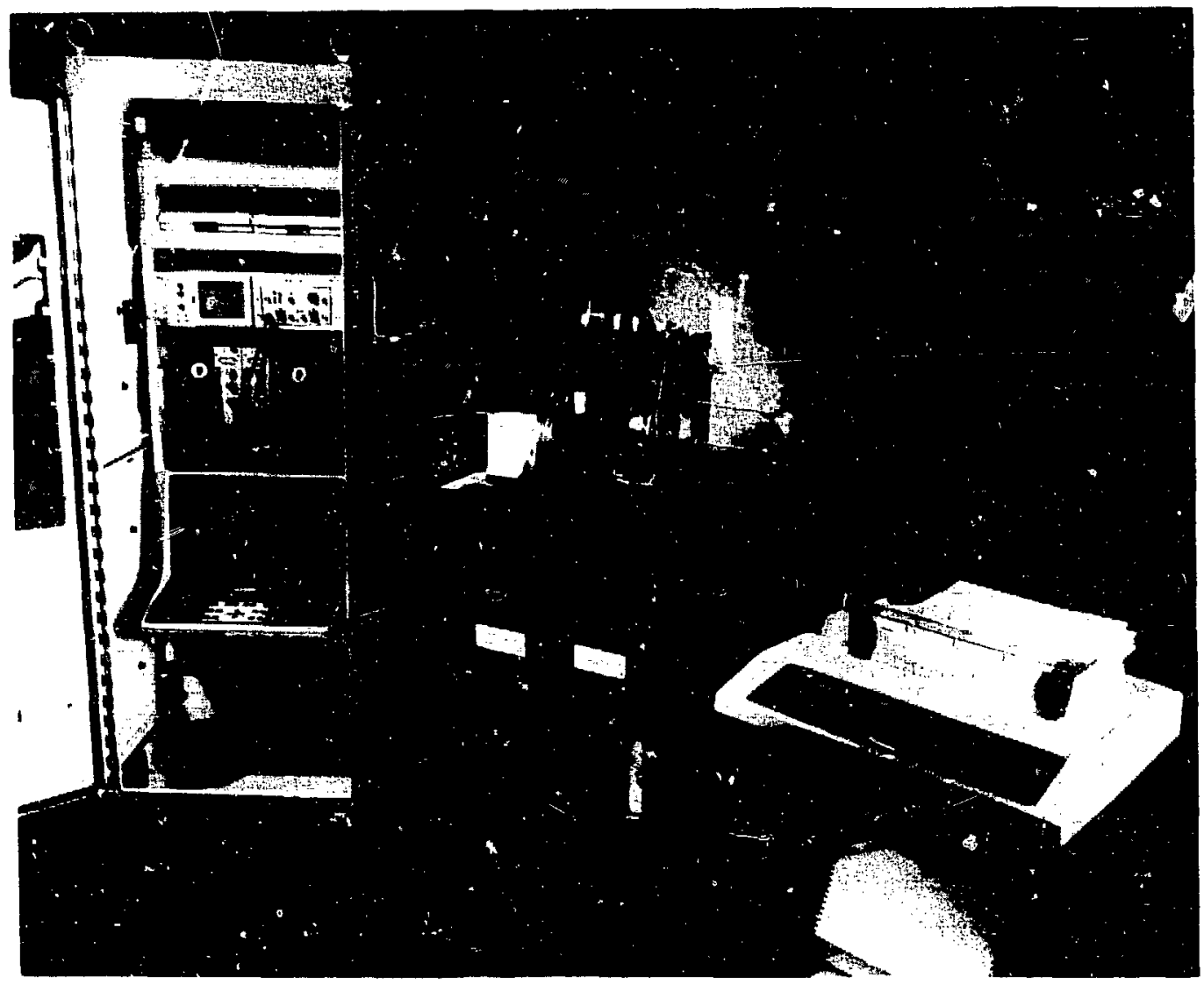

Fig. 2. AGNS L-edge densitometer equipment. The measurement station equipment, consisting of the $x$-ray generator, sample cell inside plastic containment box, and detector (obscured by the containment box), is at the center. The rack at tho lefi holds (bottom to top) the minicomputer, multichannel analyzer, NIM electronics, oscilloscope, and dual disk drives. The hard-copy terminal is at the right.

Kel $-\mathrm{F}$ transmission windows. The $\mathrm{x}$-ray generator produces a gamma-ray continuum that is used as the transmission source.

Most fielded K-edge instruments use radioisotopic transmission source: that are compact, even with shielding. The absence of natural radioisotopic sources with gamma rays that bracket the L-absorption edges is the reason that the $x$-ray generator has been used exclusively for the L-edge instruments. The range of intensitins available with the $x$-ray generator and the ability to adjust the energy to assay different elements are advantages of the $x$-ray generator as a laboratory tool that analyzes a wide range of concentrations of a variety of elements. However, the constraints of a plant laboratory or process environment cannot tolerate the bulky equipment. 
D. Scope of Compact L-Edge Evaluation

The L-edge measurements described in this report were performed using a new, compact $x$-ray generator. El imination of the bulk of the previous instruments permitted optimization of measurement geometries by reduction of source-to-sample and sample-to-detector distances.

The evaluation of this compact L-edge densitoriter included examination of the stability of the new $x$-ray generator, evaluation of the L-edge precision, investigation of possible systematic effects in the L-edge assay results, and optimization of the counting statistics. The evaluation includes an assessment of possible applications for the L-edge method.

\section{EXPERIMENTAL METHODS}

Figure 3 consists of scale drawings of the experimental setup showing the $x$-ray generator, sample coli, collimation assembly, and detector. Fig-

ure 4 is a photograph of the equipment. The compact $x$-ray generator dimensions are 10 by 14 by $15 \mathrm{~cm}$. The weight is approximately $3 \mathrm{~kg}$. The generator connects with a single cable to the external control unit, which is shown in fig. 4(a). The generator is available either as a convection- or water-cooled unit; in this case, circulated water from a commercial external cooling unit (34 by 48 by $11 \mathrm{~cm}$ ) :lowed to and from the generator through Tygon hoses. The $x$-ray tube uses a solid tungsten target with a $0.25-\mathrm{mm}$ beam spot. The voltage and current ranges of the generator are $0-25 \mathrm{kV}$ and $0-2 \mathrm{~mA}$, respectively.

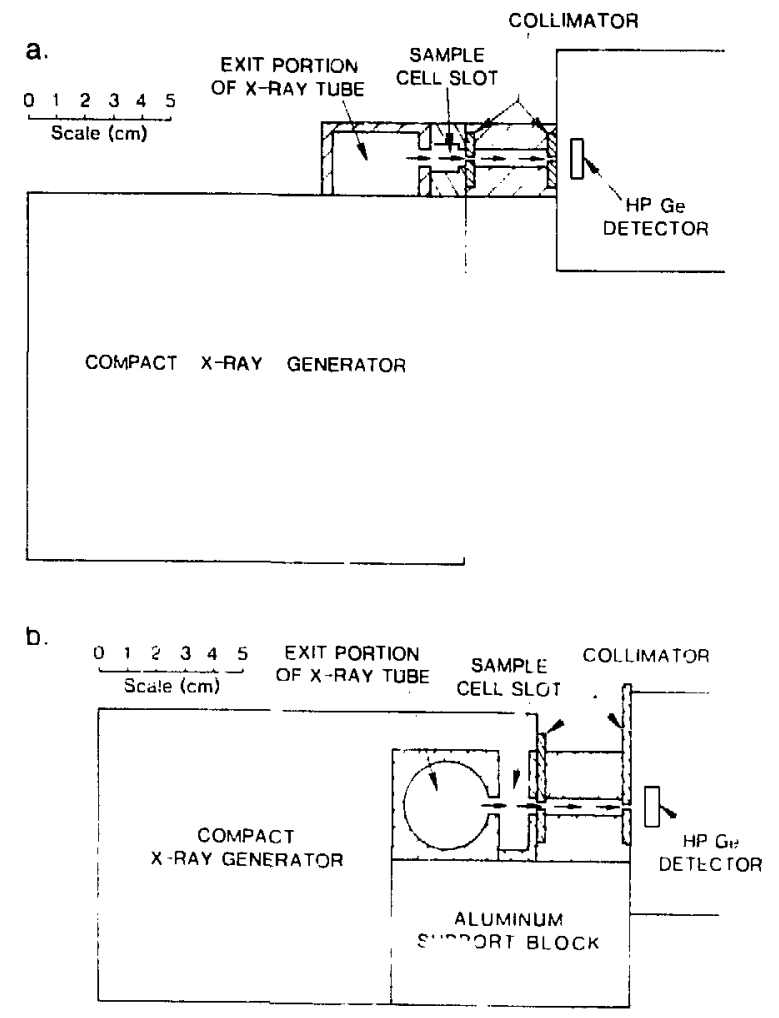

Fig. 3. Drawing to scale of crosssectional views of the experimental setup. (a) is a horizontal cross section drawn through (and parallel to) the collimated $x$-ray beam and (b) is the analogous vertical cross section showing the $x$-ray generator. sample cell slot, collimation, and detector. The cross-hatched material is brass. The horizontal arrows show the path of the $x$-ray heam. 


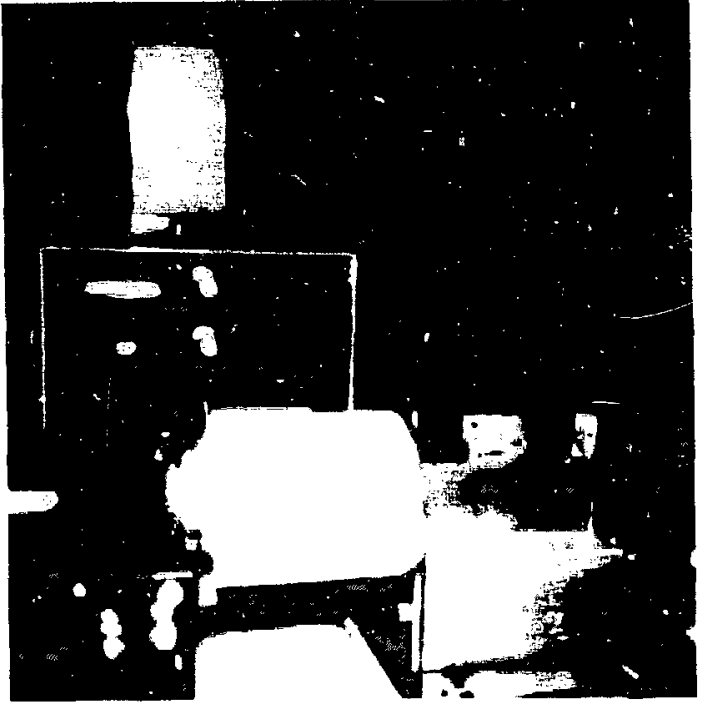

(a)

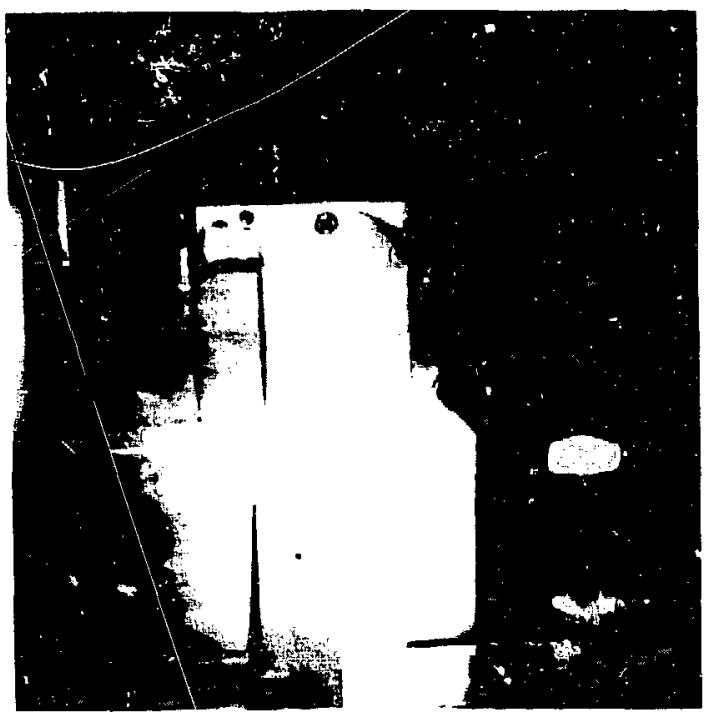

(b)

Fig. 4. Experimental setup. View (a) shows beam-collimating hardware between the $x$-ray generator and the detector, as well as the control box for the $x$-ray generator; view (b) is a close-up of the beami collimation hardware with one of the $0.16-\mathrm{cm}-\mathrm{diam}$ collimators and a sample cell in the foreground.

The $x$-ray generator spectrum was tailored to produce a continuum of $x$ rays of energies 14 to $20 \mathrm{keV}$. A sharp upper energy cutoff was achieved by placement of $0.15-m m-t h i c k$ molybdenum foil ( $K$-edge at $20.0 \mathrm{keV}$ ) between the $x$-ray generator exit window and the sample cell. The molybdenum foil also served the purpose of reducing the $x$-ray intensity to achieve the required intensity at the minimum current setting. The $x$-ray generator was operated at $20.0 \mathrm{kV}$ and the current was adjusted to achieve a count rate of $15000 \mathrm{~s}^{-1}$ in the germanium detector for each solution samplo that was assayed.

The exit window of the $x$-ray generator was $0.82 \mathrm{~cm}$ from the 1.2 -cm-wide sample cell, which was $0.32 \mathrm{~cm}$ from a 2.5-cm-1ong, 0.16-cm-diam collimator. The collimation restricted the scattering angle of the incident beam by the sample to $1.4^{\circ}$. The geometry of this setup is improved over that of previous instruments for which scattering angles were restricted to $1.7^{\circ}$ and $x$-ray source-to-sample distances were $10 \mathrm{~cm}$. The collimator was airectly in front of a planar intrinsic germanium detector.

The detector resolution was $187 \mathrm{eV}$ FWHM at $5.9 \mathrm{keV}$. An amplifier shaping time of 3 us was used during data acquisition, and pulse pileup rejection was 
employed. An analog-to-digital converter converted $10 \mathrm{~V}$ to 1024 chanrels. A ${ }^{109} \mathrm{Cd}$ source was attached to tine detector with fixed geometry. The 22.1-keV photopeak in channel 797 was used for single-point digital stabilization of gain. The spectra were stored in a computer-based multichannel anaiyzer where the display was updated in real time during data acquisition.

The sample cells used were polystyrene spectroscopic cells with inner dimensions of $1.0 \mathrm{~cm}$ by $1.0 \mathrm{~cm}$ by $4 \mathrm{~cm}$ high. The uranium concentrations of reference solutions that were analyzed were 1.021, 2.541, 5.058, 9.999, 19.941, $29.924,40.021,51.13$, and $73.97 \mathrm{~g} / \mathrm{l}$. They were made with 4 molar nitric acid and depleted uranium and were analyzed by the NBL-modified Davies-Gray procedure $^{7}$ to obtain the reference concentrations.

A spectrum of the room background (no sample cell in $p l a c e$ and $x$-ray beam

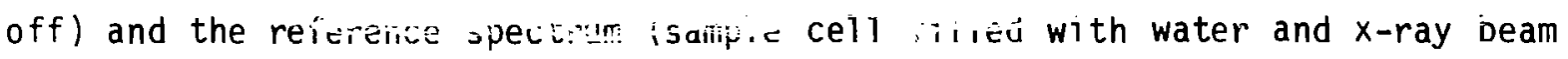
on) were collected at the beginning of each day. The reference spectrum was used to obtain the incident (or unattenuated) intensities, the $I_{0}$ values, below and above the $\mathrm{L}_{I I I}$-absorption edge. Each reference spectrum was acquired for $2000 \mathrm{~s}$, and the room background spectrum was collected for $1000 \mathrm{~s}$. Also, a 0.05 -mm-thick yttrium foil (whose $\mathrm{K}$-absorption edge at $17.039 \mathrm{keV}$ lies very close to the uranium $\mathrm{L}_{\text {III }}$-absorption edge) was analyzed each day using the same procedure used for solution analysis. The measurement control acceptability criterion for the assay of the yttrium foil was that the assay be within $0.8 \%$ (20) of the nominal value.

The solution spectra were usually collected in sets of six cycles lautocycles) of $1000 \mathrm{~s}$ each without repositioning the sample between cycles. At the luwer concentrations, where the assay sensitivity is not as good, and for thile 74-g/l solution, which did not yield a count rate of $15000 \mathrm{~s}^{-1}$, cycles were extended to 2000 or $4000 \mathrm{~s}$ at times, and the autocycles included as many as 14 cycles.

\section{RESULTS}

Figure 5 shows typical raw spectral data and the reduced data obtained by the analyses used in this experiment. The reference spectrum, Fig. 5(a), in.cludes the continuum of $x$ rays produced by the generator as well as the 22.1key photopeak that was used for gain stabilization. Figure $5(b)$ shows the 

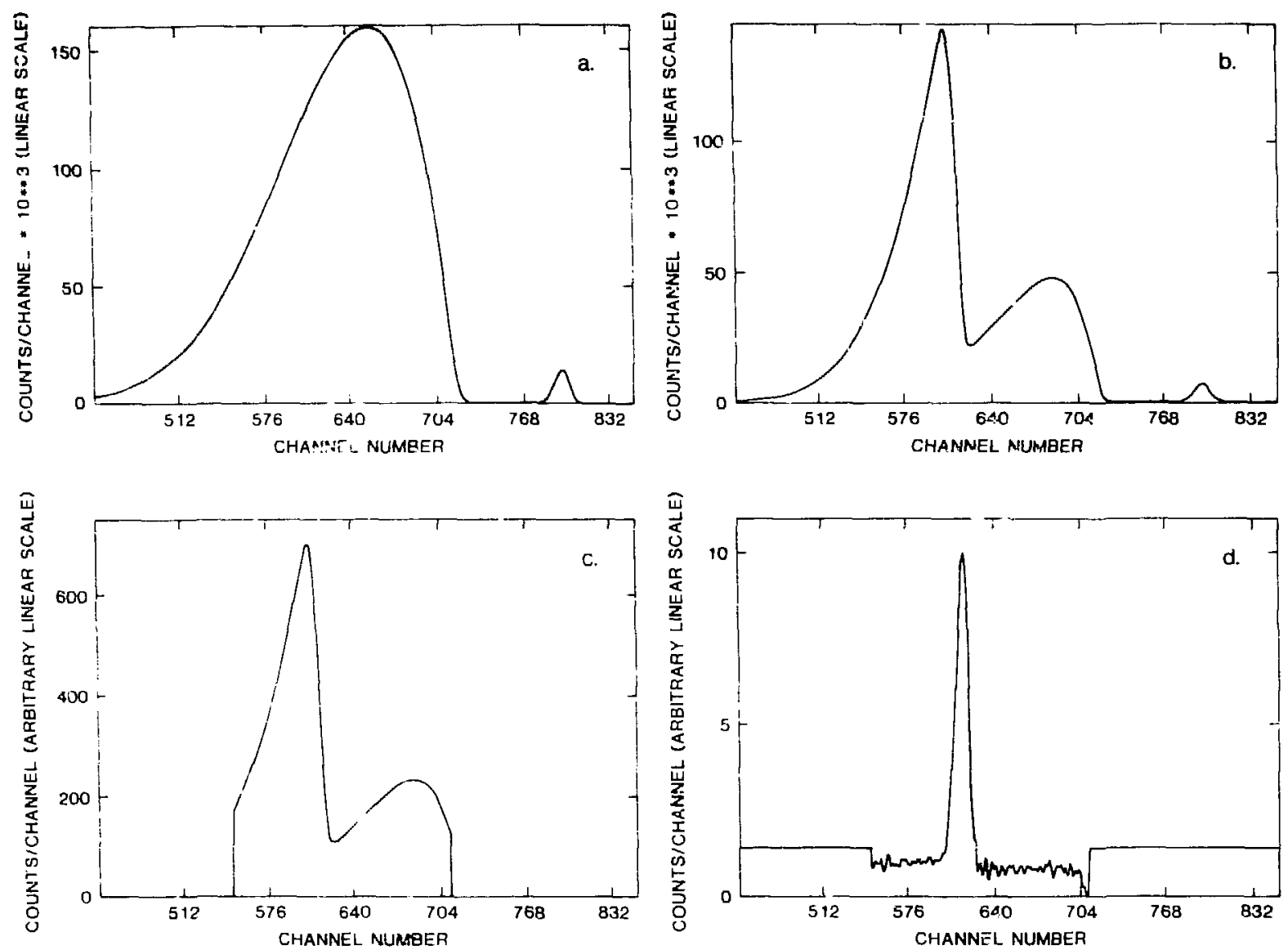

Fig. 5. An exampie of the data obtained from a uranium solution assay. Shown are (a) the reference spectrim, which includes the $x$-ray generator spectium and the 22.1-kel photopeak from the ${ }^{109} \mathrm{Cd}$ source, (b) the $x$-ray spectrum attenuated by a $40-\mathrm{g} / \mathrm{l}$. uranium solution, (c) the transmission spectrum (the solution lution spectrum divided by the reference spectrum), and (d) the difference spectrum, which is the derivative of the $l 0 g$ of the transmission spectrum.

$x$-ray spectrum transmitted through a $40-g / l$ uranium solution. The $\mathrm{L}_{I I I}$-absorption edge can be seen at $17.168 \mathrm{keV}$ (approximately channel 614). Figure 5(c) is the transmission spectrum (that is, the solution spectrum divided, channe? by channe1, by the reference spectrum). The difference spectrum, Fig. 5(d), was obtained by taking the natural logarithm of the transmission spectrum and then the channel-by-channel difference (derivative) in the vicinity of the absorption edge. Only data in channels corresponding to the regions of interest that were anaiyzed are plotted in Figs. $5(c)$ and $5(d)$.

Two methods of data analysis were used to obtain the L-edge assay result. The difference method uses tine difference spectrum illustrated by Fig. 5(d). 
The peak corresponds to the $L_{I I I}$-absorption edge of uranium, and the net area under the peak is mathematically equivalent to $\ell n R$. The linear fit method uses the transmission spectrum illustrated by Fig. 5(c). An extrapolation to the absorption edge of a linear fit to the data in regions of interest on each side of the edge gives the two transmission values used to compute the ratio R. The linear fit method has the advantage that it minimizes the statistical contribution to the random uncertainty. Analysis of the reference solutions used the measured values of $R$ and the reference values of $\rho$ to deduce the calibracion cunstant $\Delta \mu x$ from Eq. (4).

The effect that repositioning the sample cell had on assay results was tested by running 10 individual assays on a $50-\mathrm{g} / \mathrm{l}$ uranium solution, repositioning the cell between assays. Also, between assays the $x$-ray generator was turned off and turned oll again. The relative standard deviation in the 10 runs (analyzed by the difference method) was $0.28 \%$, which compares well with the predicted standard deviation of $0.26 \%$ based on counting statistics.

Figure 6 is a plot of the results of the yttrium foil assays (obtained by the difference analysis) over a 3-wk period. The error bars are the predicted

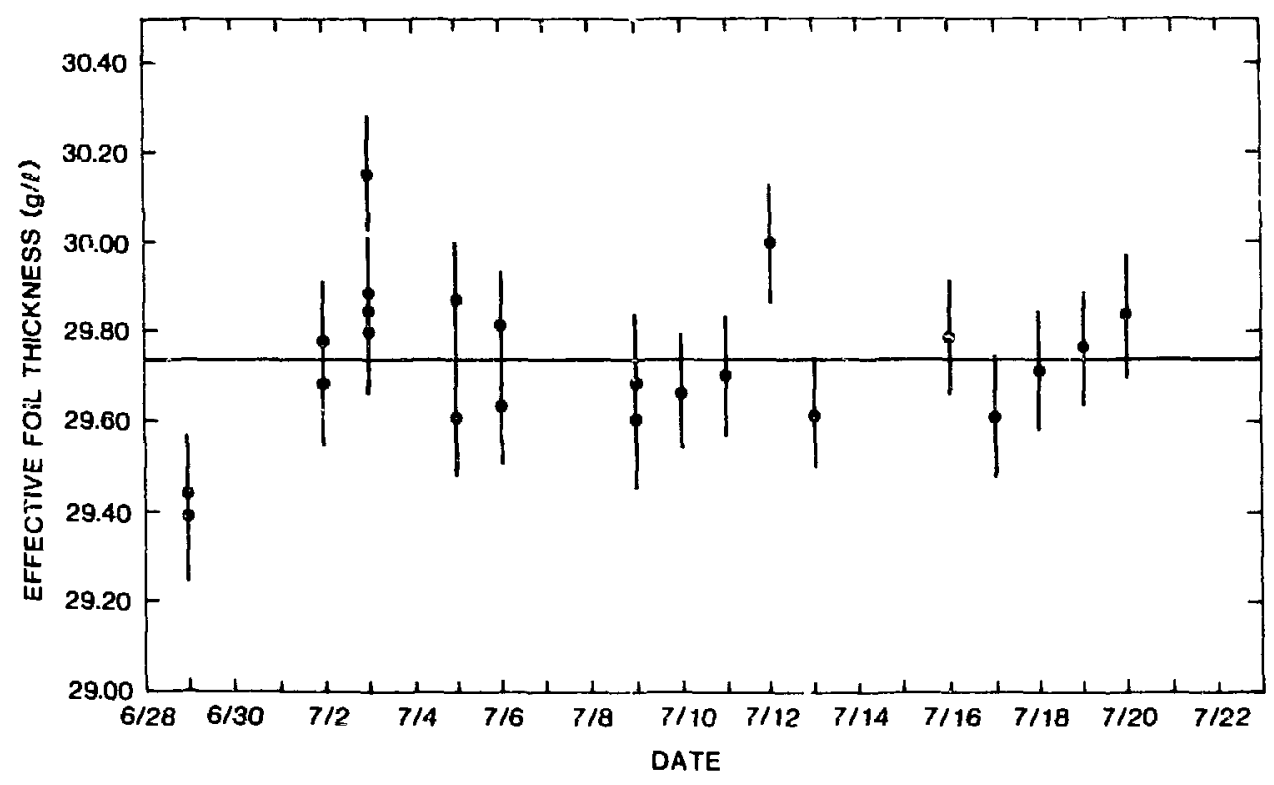

Fig. 6. The results of the yttrium foil assay are plotted vs date. The error bars are the standard deviations predicted by counting statistics $(0.43 \%)$, and the horizontal line is the average result, 29.7. The relative standard deviation in the data used to compute the average is $0.56 \%$. 
standard deviations based on counting statistics $(0.43 \%)$. The average value of 29.7 ( $\mathrm{g} / \mathrm{l}$, effective) is shown as a horizontal line. The relative standard deviation in the data used to compute the average is $0.56 \%, 1 \sigma$.

Figure 7 is a plot of the calibration constant $(\Delta \mu x)$ obtained from the difference analysis vs uranium concentration. Each point represents a single 1000-, 2000-, or 4000-s assay cycle, and those appearing in a vertical line were taken during the same autocycle. All data points in this plot were normalized to the same reference spectrum. Figure 8 is the same plot as Fig. 7 , except that the linear fit analysis was used to get the $\Delta \mu x$ values.

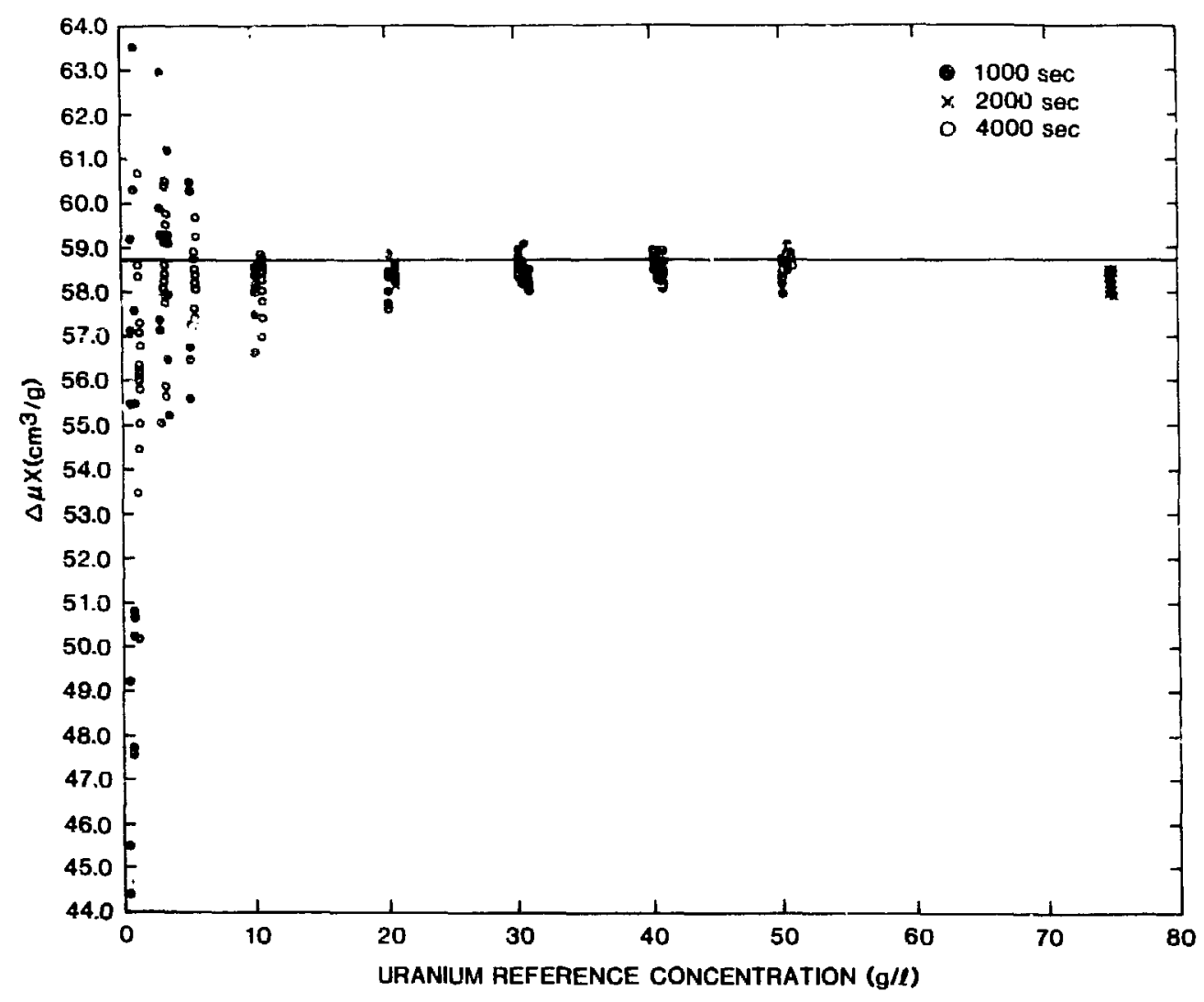

Fig. 7. A plot of $\Delta \mu x$ calculated from the difference anaiysis vs uranium concentration. (Actually, each grouping of points corresponds to a single uraniulii concentration.) All analyses were performed with the same reference spectrum. Each point represents a single $1000-, 2000-$, or $4000-s$ assay, and those points that lie in a vertical line were collected during one autocycle. (The norizontal line was computed from the 5 - to $50-\mathrm{g} / \mathrm{l}$ data shown in Fig. 9.) 


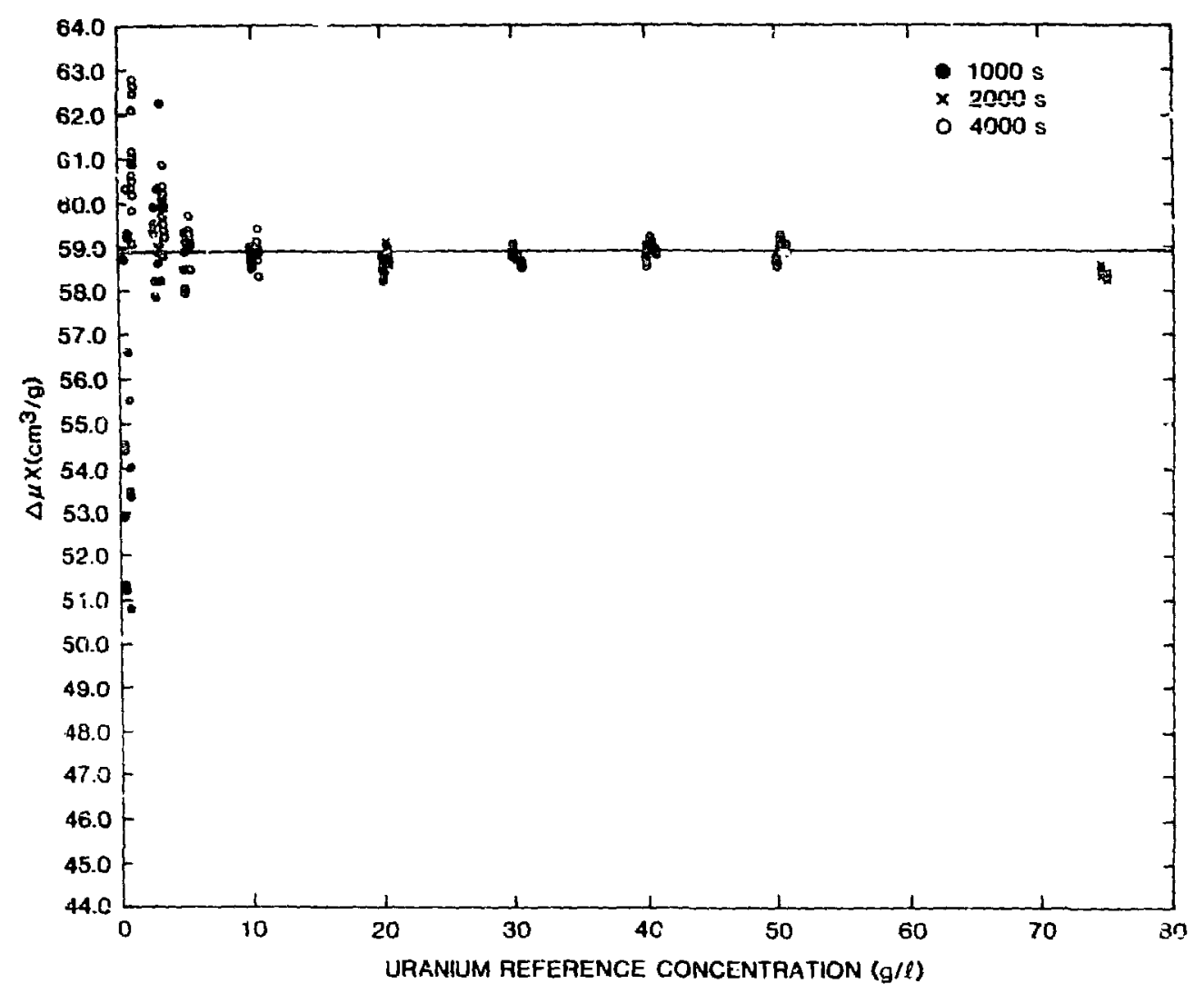

Fig. 8. The same plot as Fig. 7, except that the linear fit data analysis was used to obtain these results. (The horizontal 7 ine was computed from the 5 - to $50-g / l$ soiution data shown in Fig. 10.)

Figure 9 is a plot of $\Delta \mu x$ vs uranium concentration for the difference analysis. Each error bar is the standard deviation of five different analysis results obtained by using five different reference spectra for normalization. The horizontal line is the weighted mean $\Delta \mu x\left(58.7 \mathrm{~cm}^{3} / \mathrm{g}\right)$ computed over the concentration range of 5 to $50 \mathrm{~g} / \mathrm{l}$, inclusive. This average is also shown as a horizontal line in Fig. 7 . The relative standard deviation in the mean is $0.11 \%$.

Figure 10 is the same plot as Fig. 9, except that the linear fit analys is was used to get the $\Delta \mu x$ values. The mean value of $\Delta \mu x$ in the concentration range from 5 - to $50-\mathrm{g} / \mathrm{l}$ is shown as a horizontal line in Fig. 10 and also in Fig. 8 , and is $58.9 \mathrm{~cm}^{2} / \mathrm{g}$. The relative standard deviation in the mean is $0.10 \%$. 


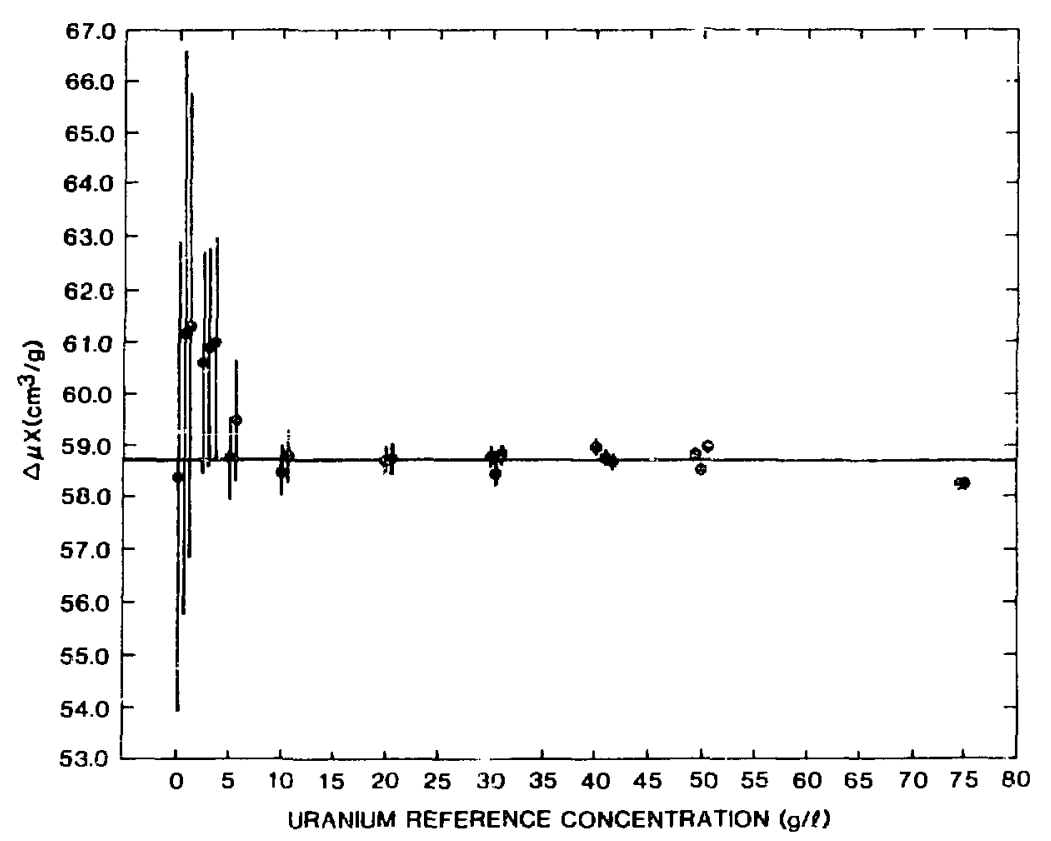

Fig. 9. A plot of $\Delta \mu x$ calculated from the aifference analysis vs uranium concentration. (Actually, each grouping of points corresponds to a single uranium concentration.) Each point represents a different autocycle assay average. The error bars give the standard deviation in five assays, each assay using a different reference spectrum but the same uranium spectra. The horizontal 1 ine is the weighted average of $\Delta \mu x$ computed over the $5-$ to $50-\mathrm{g} / \mathrm{l}$ concentration range. This same solid line has been piotted in Fig. 7 .

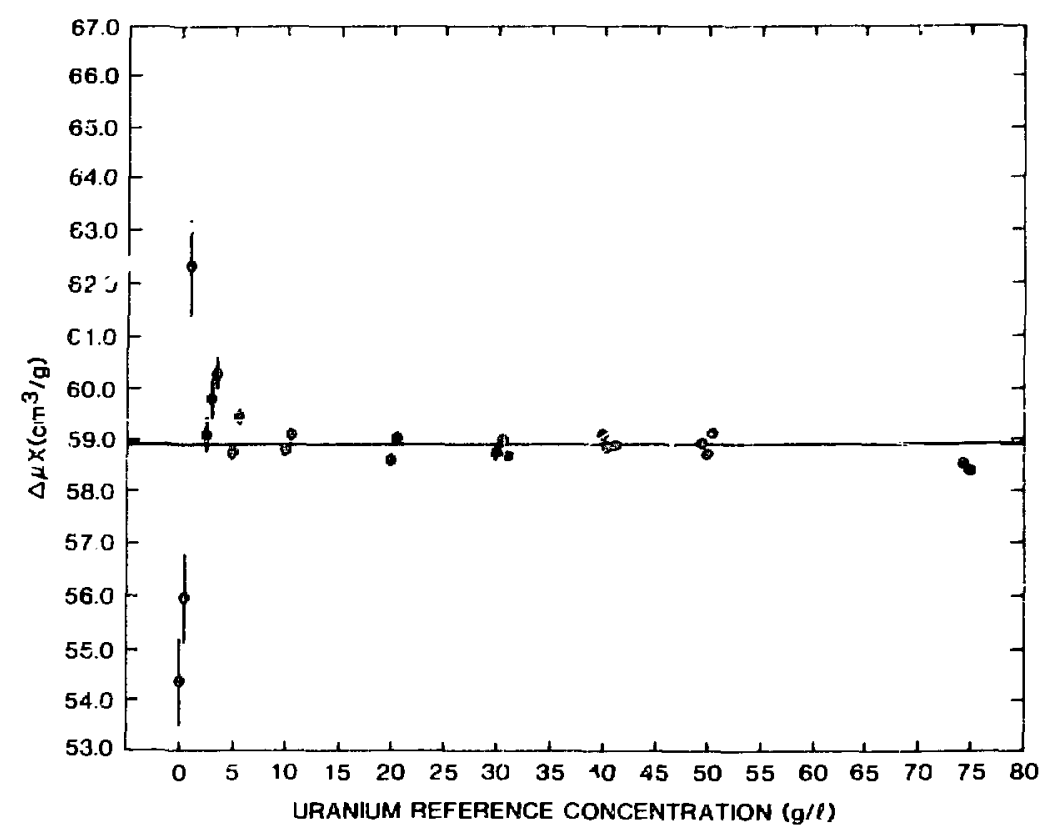

Fig. 10. The same plot as Fig. 9, except that the lirrear fit data analysis was used to obtain these results. (The horizontal line is also plotted in Fig. 8.) 
Results of the difference analysis are shown in Tab?e I. All results shown used the same reference spectrum for normalization. Column 1 lists the uranium reference concentrations of the solutions that were analyzed. The count time is the duration of the data acquisition of each cycie in the autocycle; $N$ is the number of cycles in the autocycle; $\overline{\ln R}$ and $\overline{\Delta \mu x}$ are the average values calculated from the $N$ cycles; $1 \sigma_{\text {stat }}$ is the relative standard deviation for a single cycle predicted from counting statistics [FG. (5)], and $1 \sigma_{\text {calc }}$ is the actual relative sample standard deviation within the alstocycle. The $N$ individual results used to obtain the values of $\overline{\Delta \mu x}$ in Table I are the points plotted in vertical lines in Fig. 7. Table II lists the same data analyzed

TABLE I

DIFFERENCE ANALYSIS

\begin{tabular}{|c|c|c|c|c|c|c|}
\hline 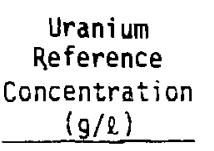 & $\begin{array}{l}\text { Count } \\
\text { Time } \\
(\mathrm{s}) \\
\end{array}$ & $\underline{N}$ & $\overline{\ln R}$ & $\begin{array}{r}\overline{\operatorname{CHX}} \\
(\ell / \mathrm{g}) \\
\end{array}$ & $\begin{array}{l}10_{\text {stat }} \\
(\mathrm{b}) \\
\end{array}$ & $\begin{array}{l}\operatorname{lo}_{\text {date }} \\
\left(\begin{array}{l}6 \\
6\end{array}\right) \\
\end{array}$ \\
\hline 73.97 & 2000 & 6 & 4.305 & 0.05820 & 0.22 & 0.30 \\
\hline 73.97 & 2000 & 6 & 4.309 & 0.05825 & 0.22 & 0.24 \\
\hline 51.13 & $? 000$ & 6 & 2.987 & 0.05842 & G. $\varepsilon 6$ & 0.50 \\
\hline 51.13 & 1000 & 6 & 3.004 & 0.05875 & 0.26 & 0.15 \\
\hline 51.13 & 1000 & 6 & 3.011 & 0.05888 & 0.26 & 0.34 \\
\hline 40.021 & 1000 & 6 & 2.348 & 0.05867 & 0.30 & 0.42 \\
\hline 40.021 & 1000 & 6 & 2.355 & 0.05885 & 0.30 & 0.45 \\
\hline 40.021 & 1000 & 6 & 2.341 & 0.05847 & 0.30 & 0.54 \\
\hline 29.924 & 1000 & 6 & 1.752 & 0.05855 & 0.39 & 0.51 \\
\hline 29.924 & 1000 & 6 & 1.765 & 0.05897 & 0.39 & 0.3 .1 \\
\hline 29.924 & 1000 & 6 & 1.743 & 0.05824 & 0.39 & 0.24 \\
\hline 19.941 & 1000 & 6 & 1.164 & 0.05839 & 0.57 & 0.78 \\
\hline 19.941 & 2000 & 6 & 1.165 & 0.05844 & 0.46 & 0.35 \\
\hline 0.999 & 1000 & 5 & 0.5851 & 0.05852 & 1.14 & 1.18 \\
\hline 9.999 & 4000 & 10 & 0.5820 & 0.05820 & 0.81 & 1.07 \\
\hline 5.058 & 1000 & 6 & 0.2989 & 0.05909 & 2.22 & 3.54 \\
\hline 5.058 & 4000 & 12 & 0.2953 & 0.05839 & 1.60 & 1.23 \\
\hline 2.541 & 1000 & 5 & 0.1544 & 0.06078 & 4.35 & 3.98 \\
\hline 2.541 & 1000 & 6 & 0.1582 & 0.06227 & 4.24 & 4.85 \\
\hline 2.541 & 4000 & 13 & 0.1514 & 0.05957 & 3.17 & 2.51 \\
\hline 1.021 & 1000 & 6 & 0.0658 & 0.06447 & 10.23 & 9.81 \\
\hline 1.021 & 1000 & 10 & 0.0694 & 0.06796 & 8.71 & 10.27 \\
\hline$\$ .021$ & 4000 & 14 & 0.0596 & 0.05834 & 8.06 & 4.31 \\
\hline
\end{tabular}


TABLE II

STRAIGHT-LINE ANALYSIS

\begin{tabular}{|c|c|c|c|c|c|c|}
\hline $\begin{array}{c}\text { Uranium } \\
\text { Reference } \\
\text { Concentration } \\
(\mathrm{g} / \mathrm{l}) \\
\end{array}$ & $\begin{array}{c}\text { Count } \\
\text { Time } \\
(5) \\
\end{array}$ & N & $\overline{\ln } \bar{R}$ & $\begin{array}{c}\overline{\Delta \mu x} \\
(2 / g) \\
\end{array}$ & $\begin{array}{l}\text { In stat } \\
(q) \\
\end{array}$ & $\begin{array}{c}10 \text { data } \\
\left(\begin{array}{l}a \\
b\end{array}\right) \\
\end{array}$ \\
\hline 73.97 & 2000 & 6 & 4.319 & 0.05839 & 0.09 & 0.18 \\
\hline 73.97 & 2000 & 6 & 4.324 & 0.05846 & 0.09 & 0.19 \\
\hline $51 . \therefore 3$ & 1000 & 6 & 2.987 & 0.05842 & 0.10 & 0.16 \\
\hline 51.13 & 1000 & 6 & 3.003 & 0.05874 & 0.10 & 0.12 \\
\hline 51.13 & 1000 & 6 & 3.000 & 0.05867 & 0.10 & 0.18 \\
\hline 40.021 & 1000 & 6 & 2.364 & 0.05907 & 0.12 & 0.16 \\
\hline 40.021 & 1000 & 6 & 2.355 & 0.05885 & 0.12 & 0.24 \\
\hline 40.021 & 1000 & 6 & 2.355 & 0.05885 & 0.12 & 0.14 \\
\hline 29.924 & 1000 & 3 & 2.354 & 0.155881 & 0.15 & 0.08 \\
\hline 29.924 & 1000 & 6 & 1.764 & 0.05896 & 0.15 & 0.17 \\
\hline 29.924 & 1900 & 6 & 1.753 & 0.05859 & 0.15 & 0.14 \\
\hline 19.941 & 1000 & 6 & 1.169 & 0.05861 & 0.21 & 0.32 \\
\hline 19.941 & 2000 & 6 & 1.174 & 0.05888 & 0.17 & 0.18 \\
\hline 9.999 & 1900 & 6 & 0.5872 & 0.05873 & 0.42 & $0.3^{7}$ \\
\hline 3.999 & 4000 & 10 & 0.5894 & 0.05895 & 0.32 & 0.54 \\
\hline 5.058 & 1000 & 6 & 0.2966 & 0.05864 & 0.83 & 1.02 \\
\hline $5 . r 58$ & 4000 & 12 & 0.2995 & 0.05921 & 0.62 & 4.48 \\
\hline 2.541 & 1000 & 5 & 0.1497 & 0.05893 & 2.92 & 1.56 \\
\hline 2.541 & 1000 & 6 & 0.1514 & 0.05957 & 2.92 & 2.52 \\
\hline 2.501 & 4000 & 13 & 0.1519 & 0.05978 & 2.10 & 1.06 \\
\hline 1.021 & $100 n$ & 6 & 0.0550 & 0.05384 & 4.41 & 2.29 \\
\hline 1.021 & 1000 & 10 & 0.0567 & 0.05548 & 4.41 & 5.87 \\
\hline 1.021 & 4000 & 14 & 0.0623 & 0.06103 & 3.18 & 1.84 \\
\hline
\end{tabular}

with the linear fit analysis. The $N$ individual results used to obtain the values of $\overline{\Delta \mu x}$ in Table II are the points plotted in vertical lines in Fig. 8.

IV. DISCUSSION

A. Performance of the Compact L-Edge Instrument

The data in Table I and the results plotted in Fig. 9 indicate that the performance of this compact densitometer is equal to that demonstrated in the evaluation of the previous instrument. ${ }^{4}$ Both evaluations show that the calibration response is flat in the concentration range from 5 to approximately 
$60 \mathrm{~g} / \mathrm{l}$ and that the precision of a $1000-\mathrm{s}(20-\mathrm{min})$ assay is $0.5 \%$ or better in the range 20 to $90 \mathrm{~g} / \mathrm{l}$. Positive and n@gative deviations from the flat calibratiol, response that occur at concentrations below $5 \mathrm{~g} / 2$ and above $60 \mathrm{~g} / \mathrm{l}$ ( $\mathrm{re}$ spectively) appear in the results of both evaluations. Because the sample cell dimensions and the data reduction and analysis methods were the same for both evaluations, the matching results indicate that the compact $x$-ray generator is a practical substitute for larger models used previously in L-edge applications, with no obvious sacrifices in performance.

\section{B. Comparison of Analys is Methods}

The previous L-edge publications ${ }^{3-6}$ gave results that were analyzed by the difference metnod only. The present analysis by the straight-line method predicts an improvement by a factor of 2.5 in assay precision over that obtained by the difference method. This is illustrated by comparing the results in the column labeled $1 \sigma_{\text {stat }}$ in Table II to the analogous results in Table I. The observed standard deviations in the results of replicate runs $11 \sigma_{\text {data }}$ in Tables I and II) show that the actual random uncertainty for the straightline method has improved by the factor predicted by counting statistics.

The appearance of systematic effects in the average results of replicate runs for the straight-line analysis (Fig. 10) indicates that the overall uncertainty (random plus systematic errors) may not be improved over that for the results of the diti=rence analysis. However, by using the straight-iine method, a cignificant decrease in counting time (to $200 \mathrm{~s}$ per assay) will yield the same precision achieved by a 1000-s assay analyzed by the difference method.

The systematic effects observed in the straight-line assay results might arise from the linear extrapolation to the absorption edge. The advantage of this extrapolation is that the matrix term in Eq. (3) is zero (because $\Delta \mu$ is zero). However, it is possible that small variations in spectral shape parameters or small changes in detector resolution ${ }^{8}$ are enhanced in the assay result by the extrapolation used in the straight-line method. For certain applications in which matrix variations from sample to sample can be ignored, it is possible to include a coistant matrix term in the analysis and to omit extrapolation to the absorption edge and still achieve the same precision demonstrated by the straight-line method. The difference method is inherently less precise than the straight-line method because fewer data puints are used in the difference analysis. 
Because the systematic effects in the straight-line method of analysis are not well understood, and because all present and previous data have been andlyzed by the difference method, the subsequent discussions draw only on results of the difference analysis. However, the improved precision achieved by using the straight-line method is large enough to justify a continued investigation of this or an equivalent approach to the L-edge analysis.

\section{Concentration Range for Precise and Timely Assay}

The ability to optimize the geometry for sample irradiation with the compact $x$-ray generator has resulted in a much more intense transmitted $x$-ray beam (despite 2.5 times less current provided by the $y$-ray generator) for the com.. pact densicometer. For this evaluation, measirements of $1-\mathrm{cm}$-thick sclution samples with uranium concentracions up to $74 \mathrm{~g} / \mathrm{l}$ were perfoned. The $x$-ray generator beam intensity was too high to use the $0.5-\mathrm{cm}$-diam collimator used in the previous L-edge evaluations, ${ }^{3-5}$ and consequently the saingie collimator diameter was reduced to $0.16 \mathrm{~cm}$. Additional attenuation (with $0.15-\mathrm{mm}$-trick molybdenum foil) was required in order to obtain the $15300 \mathrm{~s}^{-1}$ count rate for the reference spectra ( $x$ rays transmitted through a water-filled sample cell) at the minimum current setting of the $x$-ray generator. At the maximum current setting with the sample cell filled with the least transparent solution $(74 \mathrm{~g} \mathrm{U} / \mathrm{l})$, the count rate was $8000 \mathrm{~s}^{-1}$.

The results show that the criteria for timely ( $\leq 20$-min assay periods) and precise $(\leq 0.5 \%)$ assays are achieved with the experimental setup used in this evaluation in the uranium concentration range from 20 to $90 \mathrm{~g} / \mathrm{l}$, the relative precision becomes worse as $1 / 0$ (to first order), where $\rho$ is the uranium concentratior, in grams per liter, as shown by Eq. (5). However, an increased sample thickness can compensate for this effect, as Eq. (5) also shows. Figure 11 (a) is a plot of the concentration lower limit for $0.5 \%$ precision vs cell thickness. (A $1000-s$ assay of a $5-\mathrm{g} / \mathrm{l}$ solution in a $4-\mathrm{cm}-$ thick cell, for example, will be precise to $0.5 \%$.) Below these limiting concentrations, the assay precision depends only on $1 / 0$, to first order. This concentration dependence of the precision at low concentrations is shown for different cell thicknesses in Fig. 11 (b).

The attenuation of the $x$-ray beam by the solvent and the sample cell walls is a limiting factor in the maximum permissible solution thickness and in the comrosition and thickness of the sample cell walls. Table III consists of 

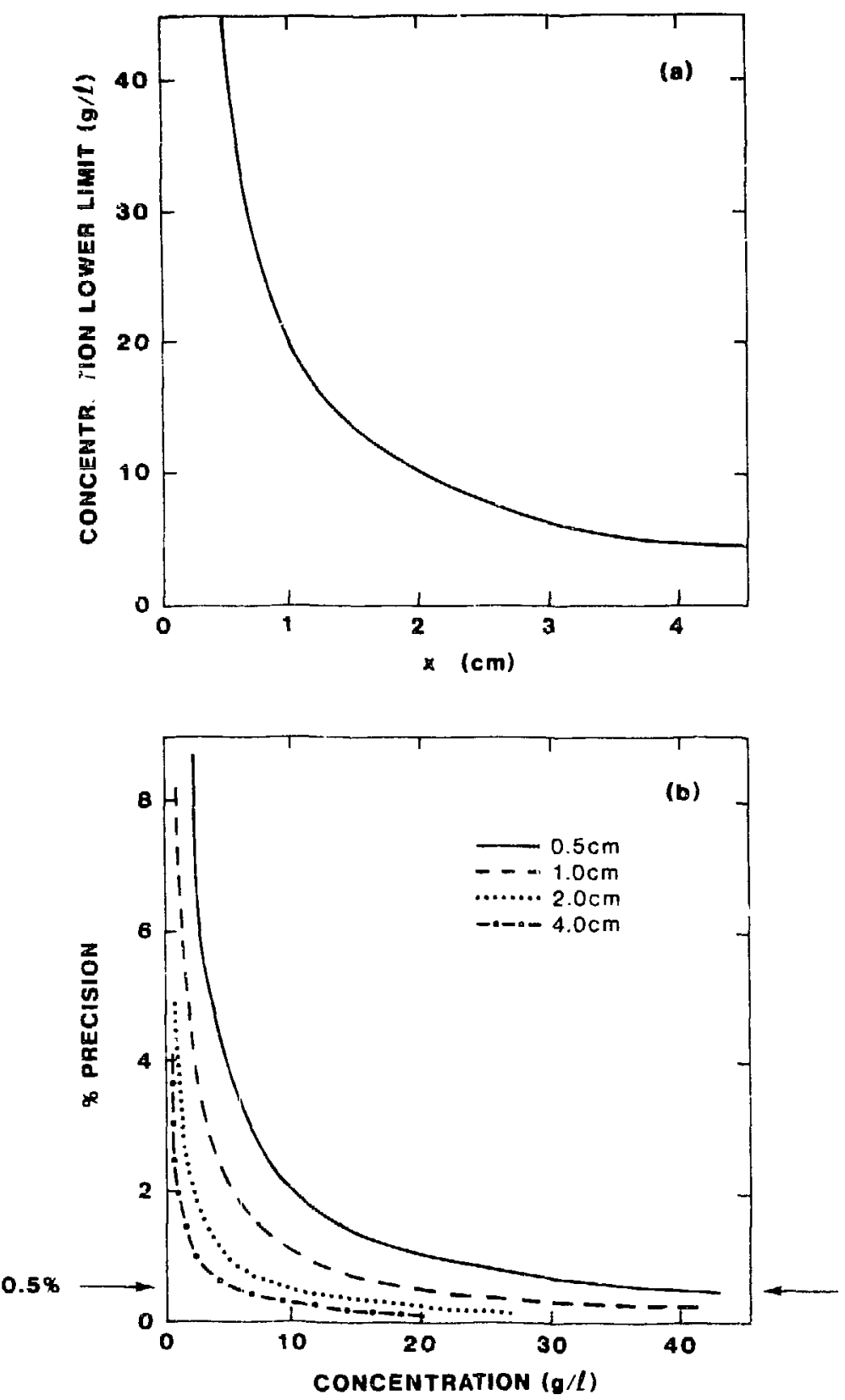

Fig. 11. (a) Plot of the lower limit of (uraniuin) concentration for $0.5 \%$ (1\%) L-edge assays in 1000-s count periods with $1-\mathrm{cm}$ transmission path lengths. (b) Plot of per cent precision (10) vs uranium concentration: [at low concentrations where the 1/0-dependence dominates in Eq. (5)] for 1000-s $L$-edge assays and different transmission path lengths. 
TABLE III

ATTENUATION DATA FOR $17.5-\mathrm{keV}$ GAMMA RAYS

\begin{tabular}{|c|c|c|c|}
\hline $\begin{array}{c}\text { Substance } \\
\text { (Empirical Formula) }\end{array}$ & Density $\left(d, \mathrm{~g} / \mathrm{cm}^{3}\right)$ & $u \cdot d\left(\mathrm{~cm}^{-1}\right)$ & $u\left(\mathrm{~cm}^{2} / \mathrm{g}\right)$ \\
\hline $\begin{array}{l}\text { Water } \\
\left(\mathrm{H}_{2} \mathrm{O}\right)\end{array}$ & 1.00 & 1.10 & 1.10 \\
\hline $\begin{array}{l}\text { Polyethylene } \\
\left(\mathrm{C}_{2} \mathrm{H}_{4}\right)\end{array}$ & 0.95 & 0.51 & 0.53 \\
\hline $\begin{array}{l}\text { Polystyrene } \\
\left(\mathrm{C}_{2} \mathrm{H}_{2}\right)\end{array}$ & 1.05 & 0.57 & 0.54 \\
\hline $\begin{array}{l}\text { Polyvinyl chloride (PVC) } \\
\left(\mathrm{C}_{2} \mathrm{H}_{3} \mathrm{Cl}\right)\end{array}$ & 1.38 & 6.7 & 4.84 \\
\hline $\begin{array}{l}\text { Teflon } \\
\left(\mathrm{C}_{2} \mathrm{~F}_{4}\right)\end{array}$ & 2.2 & 4.4 & 1.99 \\
\hline $\begin{array}{l}\mathrm{Ke}]-\mathrm{F} \\
\left(\mathrm{CCl}_{2} \mathrm{~F}_{2}\right)\end{array}$ & 2.2 & 18.0 & 8.2 \\
\hline $\begin{array}{l}\text { Pyrex } \\
\left(\mathrm{SiO}_{2}\right)\end{array}$ & 2.2 & 8.0 & 3.6 \\
\hline $\begin{array}{l}\text { Glass } \\
\left(\mathrm{SiO}_{2}\right)\end{array}$ & 2.6 & 10.2 & 3.9 \\
\hline $\begin{array}{l}\text { Aluminum } \\
\text { (A) ) }\end{array}$ & 2.7 & 14.8 & 5.5 \\
\hline Iron & 7.9 & 319 & 40.4 \\
\hline $\begin{array}{l}\text { Molybdenum } \\
\text { (Mo) }\end{array}$ & 9.0 & 174 & 19.3 \\
\hline
\end{tabular}

gamma-ray attenuation data for relevant absorbing materials for a gamma-ray energy of $17.5 \mathrm{keV}$ (midway between the uranium and plutonium $\mathrm{L}_{\text {III }}$-absorption edges). The product of the mass attenuation coefficient $\mu$ and the density $d$ appear in the exponent of the expression for gamma-ray transmission:

$$
T=e^{-\mu d x},
$$

where $x$ is the thickness of the absorber. The transmission of 17.5-keV garma rays through a given thickness of chlorine-substituted plastic (such as Kel-F) is equivalent to the transmission through a much thicker nonsubstituted plastic 
(polystyrene that is 32 times thicker than Kel-F, for example). This is the result of both the larger $\mu$ values for the higher $-Z$ elements (such as chlorine) and the larger densities of the substituted hydrocarbon plastics. Furthermore, each centimeter of water in the transmission path reduces the transmission by a factor of 3 .

Table IV is a ratio of the transmission $T$ through the sample cell and water solvent (for different cell-material and solution-thickness combinations) to the transmission $T_{M o}$ through the $1-\mathrm{cm}$ water-filled polystyrene cell (the cell used in this evaluation) plus the $0.15-\mathrm{cm}-$ thick molybdenum foil. The molybdenum alone reduces the transmission at $17.5 \mathrm{keV}$ by a factor of 14.1 , as indicated by the value of the ratio entered for the $1.0-\mathrm{cm}$ polystyrene cell. The ratio gives the intensity factor for the transmitted $x$-ray beam (at 17.5 $\mathrm{keV}$, which is the approximate centroid of the $x$-ray generator spectrum) with the moiybdenum foil removed and with the cell material and/or transmission path length varied from those used in this evaluation. Replacement of the $0.16-\mathrm{cm}$. diam collimator with the $0.5-\mathrm{cm}-\mathrm{diam}$ collimator used in previous evaluations

TABLE IV

INTENSITY FACTOR, T $\div$ TMO AT $17.5 \mathrm{keV}$

Cell Material

(Single Wall Thickness)

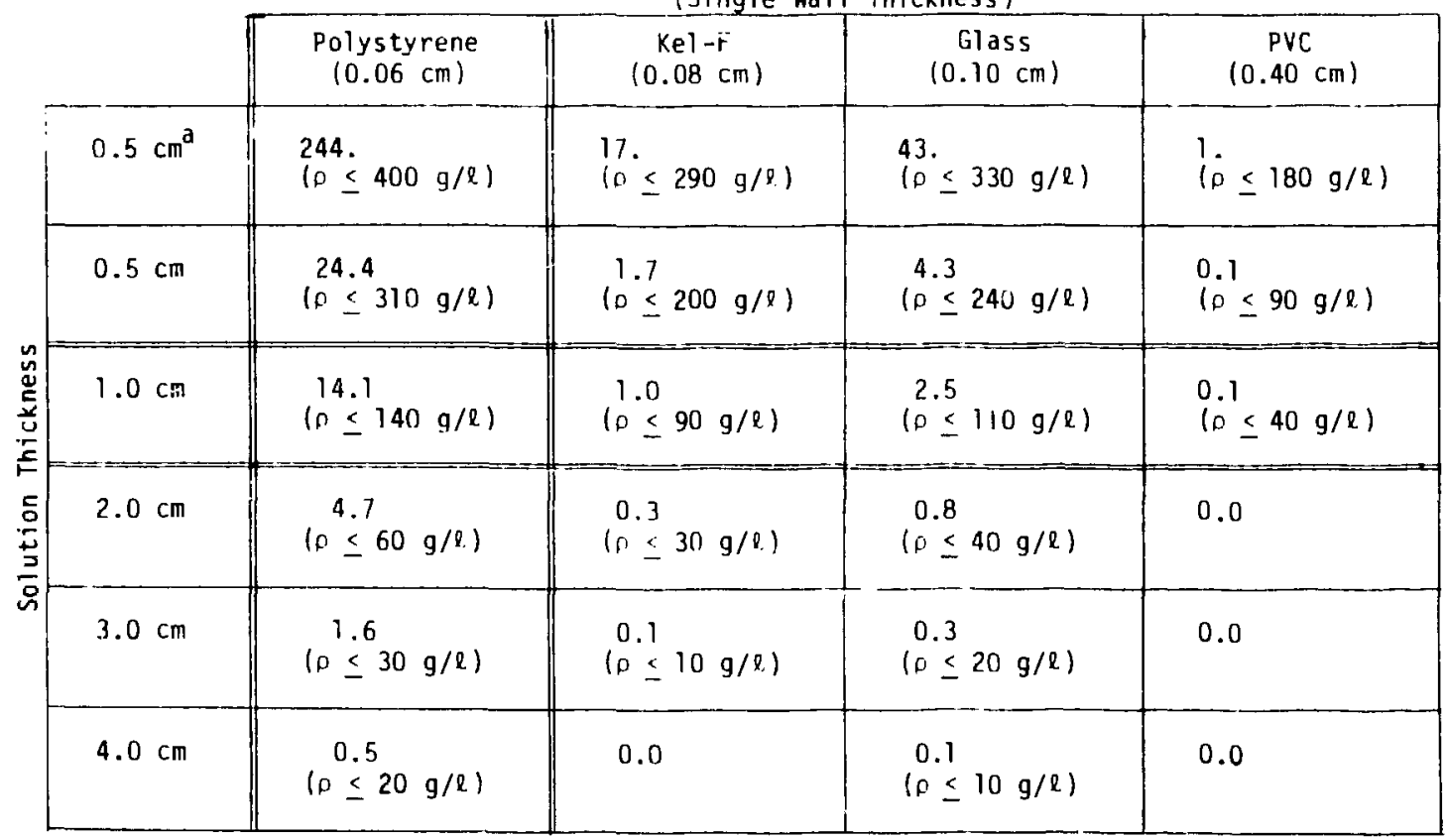

acollimator diameter $=0.5 \mathrm{~cm}$. 
increases the dotector count rate by a factor of 10, as indicated by the first and second rows of values for the intensity facior. The polystyrene and Kel-.F cell wall thicknesses given in Table IV match those of the polystyrene cells used in this evaluation and those of the Kel-F cells used in the previous L-edge evaluations. ${ }^{3-5}$ The glass cell dimensions match those of standard glass or quartz cells (manufactured for visible or ultraviolet spectroscopy) that might also be used for L-edge measurements. The heavy-walled PVC "cells" might actually correspond to thick PVC tubing bearing solutions from process vessels.

The upper limit on solution concentration for a high-precision assay with a given measurement configuration is the computed maximum uranium or plutonium co.centration for which a $0.5 \%$ assay can be achieved in $\leq 20 \mathrm{~min}$. These $1 \mathrm{im-}$ its are the parenthetical entries in Table IV. In this evaluation, the detector count rate at $74 \mathrm{~g} / \ell$ was $8000 \mathrm{~s}^{-1}$ with the maximum $x$-ray generator current setting. The precision of a 20-min assay, computed from Eq. (5), was $0.3 \%$. At $85 \mathrm{~g} / \mathrm{l}$, the detector count rate would be reduced to $25000 \mathrm{~s}^{-1}$ and the $20-\mathrm{min}$ assay precision would be $20.5 \%$, primarily because of the very low count rate above the absorption edge at the higher concentration. Therefore, to achieve $0.5 \%$ precision in 20 min with the experimental setup used in this evaluation, the uranium concentration must be in the range from 20 to $85 \mathrm{~g} / \mathrm{l}$. However, by removal of the molybdenum foil (increasing the beam intensity by a factor of 14), the upper linit to the uranium concentration range increases to $140 \mathrm{~g} / \mathrm{l}$, as indicated ir Table IV. Furthermore, by reducing the folystyrene sample cell thickness to $0.5 \mathrm{~cm}$ and replacing the $0.16-i_{1-1}-d i a m$ collimators with $0.5-\mathrm{cm}-\mathrm{diam}$ collimators, the upper limit rises to $400 \mathrm{~g}, \ell$. Therefore, it is practical to define the weful high-precision $10.5 \%$ results in $20 \mathrm{~min})$ range as $5 \mathrm{~g} / \mathrm{l}$ to $400 \mathrm{~g} / \mathrm{l}$.

To achieve high precision, a measurement station is required in which col1 imators can be interchanged, molybdenum absorbers can be inserted and removed, sample cell thicknesses can be varied, and polystyrene cells can be used to contain soiutions. For uranium or plutonium solutions, these requirements constrain solution handling operations to a well-controlled environment such as that provided by a dedicated glove box. However, this type of performance (wide range with high precision over the entire range) is usually required of a laboratory instrument that measures a large number of discrete samples removed from numerous process locations. 
A production instrument dedicated to a specific stream might address a limited concentration range and could be fabricated with a fixed configuration (solution thickness, molybdenum absorber thickness, and collinator dimension) designed for optimum precision in that range. In such applications, a flowthrough cell might be desired. Using the examples of the thick-wall pVC tubing in Table IV, the useful range for high precision with the $0.5-\mathrm{cm}-$ thick solution is 40 to $180 \mathrm{~g} / \mathrm{l}$ with the larger collimator and 40 to $90 \mathrm{~g} / \mathrm{l}$ with the sma!ler collimator.

D. Fission Product Sensitivity Limits

A previous evaluation of the L-edge sensitivity to fission products ${ }^{6}$ showed that the assay method can tolerate solution fission product levels up to $4 \mathrm{Ci} / \mathrm{g} \mathrm{Pu}$ (or $U$ ) in the assay solutions with the origina? L-edge instrument design using a $0.25-\mathrm{cm}$-dian collimator. Because of improved geometry in the new compact instrument, the equivalent sample cell $(1-\mathrm{cm}$ solution thickness, $\mathrm{Kel}-\mathrm{F}$ vindows) can be used with more restrictive collimation to assay the same concentration range with high precision and with a higher tolerance to fission products. This qualifies the L-edge method as a practical approach to the assay of uranium or plutonium in solution streams beyond the first fission product extraction in reprocessing and perhaps farther upstream for uranium assay.

\section{E. Summary and Conclusions}

The evaluation of the compact L-edge densitometer has shown that the performance of this instrument equals that of L-edge instruments demionstrated previousiy in terms of the stability of the electronics and the precision and accuracy of the assays performed in short count times. As a wide-range anaiytical tool, $0.5 \%$ precision can be achieved in 20 min or less for assays of uranium or plutonium concentration up to $400 \mathrm{~g} / \mathrm{l}$. A specific instrument of this type might use polystyrene cells with two alternative cell thicknesses, $2.0 \mathrm{~cm}$ (with a $0.5-\mathrm{cm}$ collimator diameter) and $0.5 \mathrm{~cm}$ (with a $0.16-\mathrm{cm}$ collimator aiameter), to measure the lower and upper portions (respectively) of the concentration range. The assay precision, Eq. (4), is plotted vs concentration for the alternative cells in Fig. 12. The minimum precision of $0.2 \%$ is defined by the short count time $(20 \mathrm{~min})$ and optimum count rate $\left(15000 \mathrm{~s}^{-1}\right)$ requirements. The $2.0-\mathrm{cm}$-thick cell gives the required $0.5 \%$ precision in the concentration range from $10 \mathrm{~g} / \ell$ to $60 \mathrm{~g} / \mathrm{l}$, and the $0.5-\mathrm{cm}$-thick cell satisfies the 


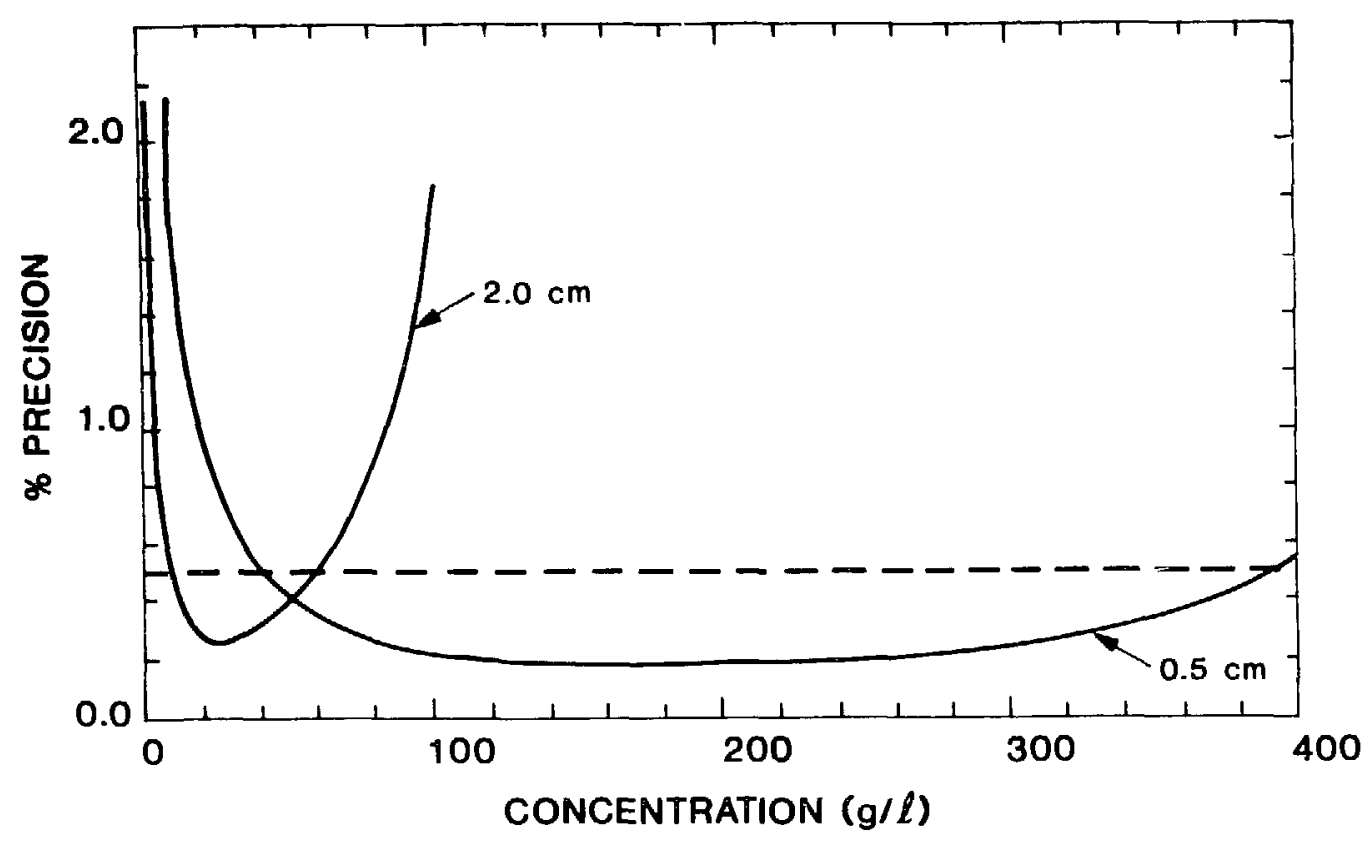

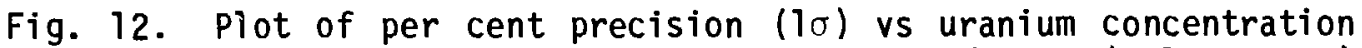
calculated for 20-min L-edge assays using two different (polystyrene) cell thicknesses. The dashed line $(10=0.5 \%)$ defines the highprecision concentration range for each cell thickness.

precision requirement in the range from $40 \mathrm{~g} / \mathrm{l}$ to $400 \mathrm{~g} / \mathrm{l}$. These range results are in agreement with previous calculations ${ }^{9}$ of the useful concentration range for L-edge assays. By using new state-of-the-art high-count-rate technologies ${ }^{10}$ for high-resolution gamma-ray detectors, $c r$ by using the straightline data analysis methods, the short-count-time criterion of 20 min can be reduced by a factor of 4 or more for high-pmerision performance in the same concentration range.

Because of the improved geometry that is possible with the compact $x$-ray generator, a good portion of the full high-precision range, namely 40 to 180 $\mathrm{g} / \mathrm{l}$, can be measured with thick-walled PVC surrounding the sample without violating the high-precision and short-count-time constraints. A higher tolerance to fission products is also the result of improved geometry, which allows more restrictive collimation of the sample.

The compact instrument is more suitable than previous L-edge densitometers for in-plant operation because it occupies less space, because it is easier to harden against plant environments, and because more substantial solution coniaiment can be tolerated. The use of newer, room-temperature solid-state 
detectors with intermediate resolution, which are frequently very small in size $\left(\mathrm{HgI}_{2}\right.$, for example), can now be considered for some L-edge applications because of the optimized transmission geometry in the compact instrument. Room-temperature detectors would simplify instrument hardening, further reduce demands on space, and minimize plant procedures for routine instrument maintenance. The sacrifice in energy resolution that accompanies the use of room-temperature detectors might have an insignificant effect on accuracy if the assay is dedicated to a, ucess (or process stream) with one component (uranium or plutonium) in solution.

Because all of the electronics and software needs for densitometry can be satisfied by compact programmabie multichannel analyzers, 11 it is practical to consider the design for a portable L-edge instrument that uses a portable germanium or a room-temperature detector. The portable x-ray generator, as opposed to secondary (radioisotopic) sources for the L-edge measurements, ${ }^{12}$ has the advantages of transportability, higher and tunable intensity, and longer lifetime, making it more suitable for portable applications and for wide-range and low-maintenance operation.

\section{REFERENCES}

1. T. R. Canada, D. G. Langner, and J. W. Tape, "Nuclear Safeguards Applications of Energy-Dispersive Absorption Edge Densitometry," ACS Symposium Series No. 79, Nuclear Safeguards Analysis (1979), pp. 96-123.

2. P. A. Russo, S. T. Hsue, D. G. Langner, and J. K. Sprinkle, "Nuclear Safeguards Applications of Energy Dispersive Absorption Edge Densitometry," J. Inst. Nucl. Mater. Manage. Proc., Issue IX (1980), pp. 730-772.

3. P. A. Russo, T. R. Canada, D. G. Langner, J. W. Tape, S. T. Hsue, L. R. Cowder, W. C. Mosley, L. W. Reynolds, and M. C. Thompson, "An X-ray LIIIEdge Densitometer for Assay of Mixed SNM Solutions," Proc. First Annual Symposium on Safeguards and Nuclear Material Management, ESARDA, Brussels, BeTgium (1979), pp. 235-240.

4. W. J. McGonnagle, M. K. Holland, C. S. Reynolds, N. M. Trahey, and A. C. Zook, "Evaluation and Calibration of a Los Alamos Nationai Laboratory LIII-Edge Densitometer," USDOE New Brunswick Laboratory report NBL-307 (Ju1y 1983).

5. P. A. Russo, T. Marks, Jr., M. M. Stephens, A. L. Baker, and D. D. Cobb, "Automated On-Line L-Edge Measurement of SNM Concentration for Near-RealTime Accounting," Los Alamos National Laboratory report LA-9480-MS (September 1982). 
6. P. A. Russo and S. T. Hsue, "The Effects of Fission Products on Demonstrated X-Ray and Gamma-Ray NDA Techniques Applied to Nuclear Materials Accounting in Reprocessing," los Alamos National Laboratory report LA-9254-MS (February 1982).

7. Glenn Waterbury, Los Alamos National Laboratory Quality Assurance Procedure ANC-DE = I-UA-38, R? (1977).

8. D. G. Langner, "Computer Simulation of the LIII-Edge Densitometer," Los Alamos National Laboratory report, to be published.

9. S. T. Hsue, "Densitometry Design," Los Alamos Nationai Laboratory internal document Q-1-80-243 (May 1980).

10. K. Kandiah and G. White, "Status at Harwell of Opto-Electronic and TimeVariant Signal Processing for High Performance Nuclear Spectrometry with Semiconductor Detectors," IEEE Trans. Nucl. Sci. NS-28, No. 1, (1980), pp. 613-620.

11. L. R. Cowder, S. F. Klosterbuer, and R. H. Augustson, "A Compact K-Edge Densitometer," Proc. Sixth Annual Symposium on Safeguards and Nuclear Material Management, ESARDA, Venice, I taly (1984), pp. 261-268.

12. M. Bruoks, J. Wachter, P. Russo, and R. Strittmatter, "Discrete Source LIII-Edge Densitometry for Assay of Element Concentrations of Thorium, Uranium or Plutonium," Los Alamos National Laboratory report (in preparation). 